\title{
Obituary
}

\section{A tribute to Norman L. Letvin (1949-2012)}

$\mathrm{T}$ he field of HIV/AIDS research and the scientists who seek to make an effective HIV-1 vaccine have lost one of their most influential leaders. Dr. Norman L. Letvin, Professor of Medicine, Harvard Medical School, and Chief of the Division of Viral Pathogenesis, Beth Israel Deaconess Medical Center, passed away at Brigham and Women's Hospital on May 28, 2012, at the age of 62 , following a long and courageous fight against pancreatic cancer. Norm was a world authority on the biology of retrovirus infections in nonhuman primates and was the discoverer of the SIV and the immunodeficiency disease it causes in rhesus macaques. He set the standard for the use of the SIV-infected rhesus monkey model to understand the immunopathogenesis of AIDS and to assess the efficacy of HIV-1 vaccine candidates. Above and beyond these professional accomplishments, Norm was a consummate collaborator, who fostered the development of large research teams that made remarkable progress in AIDS research. He was a loyal friend to his colleagues, a wise mentor to both trainees and collaborators, and an honest and caring advisor to all with whom he worked.

Norm received his BA (summa cum laude) from Harvard College and his MD (Alpha Omega Alpha) from Harvard Medical School. In 1976, he married a college classmate, Marion Stein (MD Johns Hopkins University School of Medicine). He returned to Boston the following year as a senior resident at the Massachusetts General Hospital, while his wife began her neurology training at the Boston University Medical Center. In 1978, he joined the laboratory of Baruj Benacerraf where he began his life-long study of the immune system and its role in the prevention of disease. From 1982 to 1994, he was the founding chair of the Division of Immunology at the New England Primate Research Center of Harvard Medical School. From 1994 until his death, he was chief of the Division of Viral Pathogenesis at Beth Israel Deaconess Medical Center, Harvard Medical School.

In the laboratory of the Nobel laureate Baruj Benacerraf, his first project was to investigate the role of UV irradiation on antigen-presenting cells (then called adherent cells) in immune system activation. Over the next three years, Norm made important observations, demonstrating the requirement of $\mathrm{T}$ cell-adherent cell interactions for response to antigens. In 1982, he accepted a Harvard faculty position within the New England Regional Primate Center, with a focus on defining the immunobiology of rhesus macaques. In 1983, Norm wrote now classic papers on the discovery of SIV and of the AIDS-like disease that it causes in rhesus macaques.

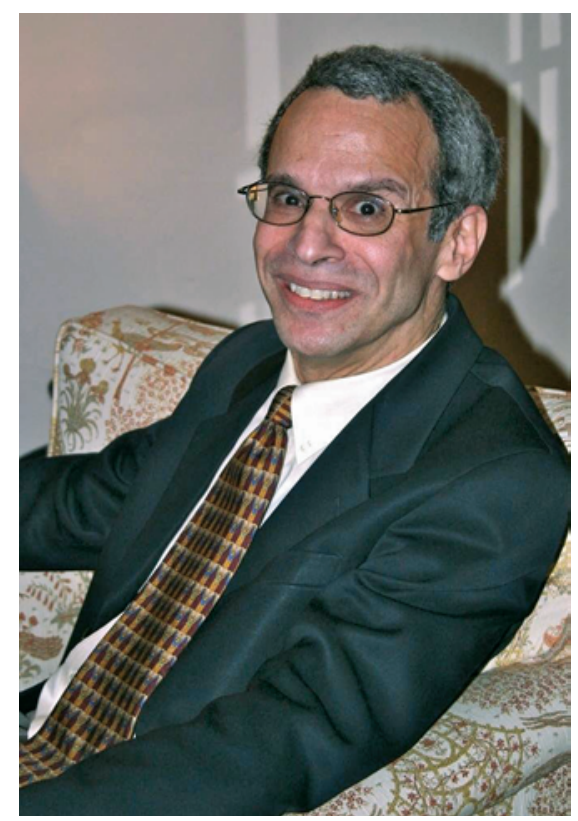

Over the next 11 years, he led the field to understand much of the fundamental principles of the cellular and molecular immunology of the primate immune system, enabling its study as a surrogate for the human immune system. In 1994, he accepted a position at the Beth Israel Deaconess Medical Center as the chief of the new Division of Viral Pathogenesis and built the division into one of the most outstanding investigative units in the world, which includes a state-of-the-art flow cytometry center that serves as a core facility to the primate center system and the Harvard medical community.

Norm played important roles in most of the major initiatives in HIV-1 vaccine development. He was principal investigator of the National Institute of Allergy and Infectious Diseases (NIAID) Primate Core Research Grant that performed T cell immunology studies for primate vaccine studies and also was a founding investigator/member of the NIH Vaccine Research Center at NIAID. He also received Collaboration for AIDS Vaccine Discovery grants from the Bill and Melinda Gates Foundation and, in 2005, was cofounder of the NIAID Center for HIV/AIDS Vaccine Immunology (CHAVI). He served for 13 years as an editor for HIV/AIDS research articles submitted to Science magazine. His academic achievements included authorship of more than 450 publications, election to the American Society for Clinical Investigation, and election to the American Association of Physicians.

In all of his academic efforts, Norm was a catalyst for hard work, collaboration, clear thinking, and incisive decision-making. Despite his numerous landmark accomplishments in the HIV/AIDS field, Norm would often reflect that one of his important contributions to human health was establishing the efficacy of hydroxyurea for increasing fetal hemoglobin production in nonhuman primates, paving the way for its use as an effective treatment of sickle cell disease. This successful work, which he achieved with the use of only two juvenile macaque monkeys, was born out of a chance conversation during an elevator ride with David G. Nathans, President Emeritus of the Dana-Farber Cancer Institute and expert in hematologic diseases of children. Norm used this anecdote among others to remind young investigators to be alert to promising research opportunities and open to unexpected collaborations.

Beyond his scientific achievements, Norm was an accomplished musician, and playing music was an important part of his life. He maintained his skills as a classical clarinetist and performed frequently in the Boston area, especially with the Weston Wind Quintet, of which he was a founding member. During his life, he performed as a chamber music recitalist in the New England area and beyond with noted musicians, including Yo-Yo Ma, with members of the Boston Symphony Orchestra, and with the Ciompi Quartet. He premiered works by several modern composers. He often provided thrilling performances of music for his CHAVI and Vaccine Research Center colleagues during their annual retreats. His interest in teaching and inspiring young people also 
extended beyond the scientific world: he was a life-long enthusiast for the Interlochen youth summer music program and was an active supporter of the HarvardRadcliffe Orchestra.

One of Norm's greatest talents was mentorship. He was devoted to the young people that he trained, undergraduates, graduate students, and postdoctoral fellows alike. He loved his students, treating them like members of his own family, and they in turn loved him. He established an open-door policy with his mentees, even providing them with his home and cell phone numbers for their use at any hour. The only time Norm was unavailable to his colleagues was Friday mornings when he was meeting with his students. He always reviewed the primary data from his trainees very carefully and taught them to read the literature critically, to write clear and concise scientific papers, to present their work effectively, and to write successful grants. Norm's mentoring accomplishments were recognized by Harvard Medical School when he was awarded the William Silen Lifetime Achievement in Mentoring Award.

Norm also excelled as a wonderful role model for how to balance work and family. A devoted father, he was an equal partner with Marion in raising and caring for his four children, Andrea, Rebecca, Adam, and Elizabeth.

Norm was an extraordinary person. His devotion to his family, to science, and to his trainees was exemplary in every way. All who knew him benefitted from interactions with him and learned from the wisdom he bestowed upon them. He was one of those rare individuals who made all those around him better. His passing is a profound loss for his family, his colleagues, and for the entire field of HIV/ AIDS research. Norm Letvin will serve as an inspiration to others to carry on the work and great challenge of developing an effective HIV-1 vaccine in his memory.

\section{Barton F. Haynes}

Duke Human Vaccine Institute, Departments of Medicine and Immunology, Duke University Medical Center, Durham, North Carolina 27707, USA. Phone: 919.684.5279; Fax: 919.684.5230; E-mail: hayne002@mc.duke.edu.

\section{Sallie Permar}

Duke Human Vaccine Institute, Department of Pediatrics, Duke University Medical Center, Durham, North Carolina 27707, USA. Phone: 919.684.2515; Fax: 919.668.4859; E-mail: Sallie.permar@duke.edu. 